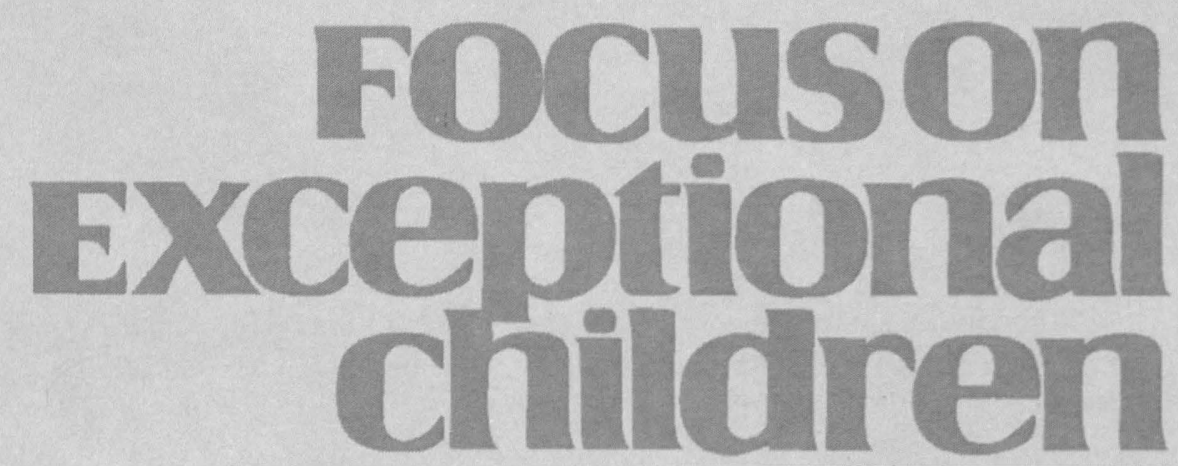

\title{
Review of Comparison Studies Investigating Bilingualism and Bilingual Instruction for Students with Disabilities
}

\author{
Gregory A. Cheatham, Rosa Milagros Santos, and Ayfer Kerkutluoglu
}

Increasingly, schools are educating bilingual students, including those with diagnosed disabilities. In school year $2008-2009,11 \%$ of students from kindergarten through twelfth grade were considered English language learners (ELLs). Of those, $7 \%$ or more than half a million English learners were served under IDEA Part B (National Clearinghouse for English Language Acquisition and Language Instruction Programs, 2011a, $2011 \mathrm{~b})$. For years, researchers have discussed the importance of culturally and linguistically appropriate practices for all learners. One component of these practices is to recognize the importance of students' home languages as well as English, particularly given the increase of English learners in school contexts (Verdugo \& Flores, 2007; Zehler et al., 2003) and in early education programs (Espinosa, 2010; Fix \& Passel, 2003; Hanson, 2011).

However, an instructional variable that is less frequently discussed for bilingual students with disabilities is the use of their home language. In 2002, Kindler reported that nationally $58.4 \%$ of prekindergarten programs and $49 \%$ of kindergarten programs provide instruction that includes children's home languages. Zehler et al. (2003) reported that $63 \%$ of English learners from kindergarten through twelfth grade who qualified for special education services received instruction all in English (compared to $59.6 \%$ of all students considered ELLs). Rasmussen (2009) reported that from 2002-2008 many states continued to provide bilingual programs for English learners from preschool through twelfth grade. However, the number of programs that use students' home language show a declining trend despite data showing an increase of English learners in schools. Thus, compared to typically developing peers who are also English learners, students participating in special education programs who are also English learners tend to be educated in English-only environments (Zehler et al., 2003). This, despite the fact that many families daily use both languages and choose bilingualism even for their children with disabilities (Jegatheesan, 2011). For example, results of a multinational survey indicated that many parents of children with autism who lived in a bilingual family were raising their children to be bilingual or multilingual (Kay-Raining Bird, Lamond, \& Holden, 2012).

Gregory A. Cheatham is assistant professor in the Department of Special Education at the University of Kansas, Rosa Milagros Santos is associate professor in the Department of Special Education at the University of Illinois at Urbana-Champaign, and Ayfer Kerkutluoglu is a doctoral student at Mary Lou Fulton Teachers College, Arizona State University. 
In the United States, the development of children's home language along with English (often referred to as bilingual approaches) faces many challenges. Among these challenges are not only questions about instructional effectiveness but also about the extent to which taxpayer-funded public schools should be engaged in teaching and supporting students in a language other than English. A powerful subtext to these arguments may be that bilingual students are expected to conform and quickly assimilate to mainstream culture and language (i.e., white, middle-class, and English speaking; Artiles \& Ortiz, 2002). As a result, there has been a policy shift away from bilingual instruction. For instance, Arizona and California require English-only approaches to instruction for English learners with only a few exceptions (Arizona Revised Statutes, 2001; California Education Code, 1998). Additionally, because No Child Left Behind (2001) soon to be renamed the Elementary and Secondary Education Act - requires standardized assessment only in English; students' home languages and associated literacies are deliberately not supported (Baker, 2011; Menken, 2009). Compounding this issue is that even when bilingual programs are

\section{Focuson
Exceptional children}

ISSN 0015-511X FOCUS ON EXCEPTIONAL CHILDREN (USPS 203-360) is published monthly except June, July, and August as a service to teachers, special educators, curriculum specialists, administrators, and those concerned with the special education of exceptional children. This publication is annotated and indexed by the ERIC Clearinghouse on Handicapped and Gifted Children for publication in the monthly Current Index to Journals in Education (CIJE) and the quarterly index, Exceptional Children Education Resources (ECER). The full text of Focus on Exceptional Children is also available in the electronic versions of the Education Index. It is also available in microfilm from Serials Acquisitions, National Archive Publishing Company, P.O. Box 998, Ann Arbor, MI 48106-0998. Subscription rates: individual, \$50 per year; institutions, \$68 per year. Copyright (C) 2012, Love Publishing Company. All rights reserved. Reproduction in whole or part without written permission is prohibited. Printed in the United States of America. Periodical postage is paid at Denver, Colorado. POSTMASTER: Send address changes to:

Love Publishing Company

Executive and Editorial Office P.O. Box 22353

Denver, Colorado 80222

Telephone (303) 221-7333

\section{CONSULTING EDITORS}

Steve Graham Vanderbilt University
Ron Nelson University of Nebraska-Lincoln

Eva Horn

University of Kansas available, there is a dearth of qualified bilingual educators and bilingual special educators (Daunic, Correa, \& ReyesBlanes, 2004; Hoover, Klingner, Baca, \& Patton, 2008; National Research Council, 2002).

While the use of the home language for bilingual students with disabilities has received some attention, educational placements (i.e., least restrictive environment) to appropriately address both disability and bilingual language needs have not been adequately addressed. As Turnbull, Stowe, and Huerta (2007) asserted, IDEA (2004) requirements assume that special education services occur within inclusive environments (i.e., general education classes) with appropriate aids and services. However, methods with which inclusive services are bilingually provided is an understudied pedagogical approach. Given the complexities of providing both special education and home language support for students with disabilities, more research is needed.

\section{STATEMENT OF PURPOSE}

The purpose of this article is to provide a narrative review of comparison studies regarding the impacts of bilingualism and interventions including the home and second language for students with disabilities. Although research is limited, preliminary findings from existing studies illustrate that bilingualism does not negatively impact language or academic abilities for students with disabilities. Additionally, researchers suggest that instruction in and through the home and second language does not negatively impact language and academic abilities of students with disabilities assessed within these studies. We conclude with a discussion of steps forward, given that acceptance and promotion of bilingualism cannot only be effective for students with disabilities but also is a component of culturally and linguistically appropriate services for bilingual students with disabilities.

\section{SEARCH PROCESS AND CRITERIA}

In this article, we examine published studies that explicitly compared communication, cognitive, and behavioral outcomes of bilingualism and instruction including the home language. We define comparison studies as those that compared bilingual students with disabilities to (a) typically developing bilingual students and/or (b) monolingual students with disabilities. Additionally, we include studies that compared outcomes of home language and bilingual intervention or instruction for students with disabilities compared to instruction only in the second language. Outcome measures included students' communication, cognitive, academic, and behavioral performance, depending on the specific study.

Studies selected were identified through the following databases: PsychInfo, EBSCO, Linguistics and Language 
Behavior Abstracts, Social Science Citation Index, Education Full Text, ERIC, and Google Scholar. Search key words included the following: English as a second language, English language learners, bilingual special education, limited English proficient, language delay, early childhood education, early childhood special education, language impairment, preschool education, disability, mental retardation, mental impairment, autism, speech impairment, speech delay, aphasia, traumatic brain injury, learning disability, dyslexia, and Down syndrome.

These comparison studies are reviewed with an understanding that comparisons between bilingual and monolingual students warrant caution. Researchers, educators, and families should not assume that monolingualism is the norm to which bilinguals should be compared (Bassetti \& Cook, 2011; Grosjean, 1985). As such, both research and instructional practice can avoid a monolingual bias (Bassetti \& Cook, 2011). To this point, "bilinguals are speakers-hearers in their own right who will often not give exactly the same kinds of [assessment] results as monolinguals" (Grosjean, 1998, 134). For example, bilinguals' two languages rarely mirror one another (i.e., balanced bilinguals), but proficiencies include communication strengths to appropriately function in different environments with different speakers (Cobo-Lewis, Pearson, Eilers, \& Umbel, 2002; Grosjean, 1998; Oller, Pearson, \& Cobo-Lewis, 2007). To illustrate, food vocabulary typically is more developed in the home language than the second language, because preparing and eating occurs at home with family using the home language. Consequently, rather than an indicator of linguistic deficit, variable communication skills specific to each of a bilinguals' languages are natural and need to be considered when comparing competencies of students who are bilingual to those who are monolingual.

Nonetheless, reviewing comparison studies is one researchbased approach to understand students' development in two languages and to move toward evidence-based practices for bilingual students with disabilities, such as language(s) of instruction. The next section is structured in the following way: First, we discuss disability and bilingualism through a review of comparison studies in which researchers investigated impacts of bilingualism for students with disabilities. Second, we discuss disability and bilingual intervention/instruction by reviewing studies that compare intervention/instruction including two of the following: home language, both languages, and second language.

\section{DISABILITY AND BILINGUALISM}

Despite evidence to the contrary, there is a pervasive belief in the special education field that bilingualism increases risks for children with disabilities and should be avoided (Baker, 2011; Paradis, Genesee, \& Crago, 2010). Certainly, bilingual students with disabilities exhibit learning difficulties compared to typically developing bilingual students. However, bilingualism does not cause or compound disability; furthermore, students with disabilities can and do become bilingual (Cheatham, Santos, \& Ro, 2007; Gutierrez-Clellen, 1999), as illustrated in the discussion of comparison studies below.

\section{Outcomes for Bilinguals with Disabilities Compared to Bilinguals without Disabilities}

Researchers found that bilingual children with disabilities tend not to perform as well as bilingual children without disabilities on academic and linguistic measures. These outcomes are not surprising and in part illustrate that a disability (e.g., language disability, Down syndrome, reading disabilities) has a significant impact on children's communication skills (e.g., grammar, phonology, vocabulary, and narrative skills; Hakansson, Salameh, \& Nettelbladt, 2003; Jacobson \& Schwartz, 2002, 2005; Kay-Raining Bird et al., 2005; McCabe \& Bliss, 2005; Salameh, Nettelbladt, \& Norlin, 2003). Additionally, in one study researchers investigated impacts on reading skills for bilingual students with learning disabilities with similar outcomes (Abu-Rabia \& Siegel, 2002).

To illustrate, in two separate studies, Jacobson and Schwartz $(2002,2005)$ compared early 7- to 9-year-old Spanish-English bilingual children with language impairments to typically developing bilingual children regarding their English grammar skills (i.e., past tense, morphology). They found that typically developing bilingual children were more accurate in the assessed grammatical skills than comparable bilingual children with disabilities.

In a similar study, Hakansson, Salameh, and Nettelbladt (2003) studied the grammar (e.g., morphology and clause structure) in two languages (i.e., Swedish and Arabic) of typically developing 3- to 6-year-old bilingual children and compared them to matched peers with language impairments. Assessing tasks in Swedish and Arabic, the researchers found that the order in which the children developed grammatical constructs was similar for the two groups of children. Additionally, they found that the bilingual children with language impairments exhibited lower communication performance levels compared to their typically developing bilingual peers. Thus, as expected, the outcomes of these studies illustrated that the bilingual children with disabilities exhibited learning difficulties compared to bilingual children without disabilities. Taken together, these studies suggest that, when communication skills are affected by disability, difficulties are exhibited in both of the students' languages.

\section{Outcomes for Bilinguals with Disabilities Compared to Monolinguals with Disabilities}

Of great interest to researchers, educators, and families are outcomes of studies comparing the performance of bilingual 
students with disabilities to that of monolingual students with disabilities. These studies provide evidence for the impact of bilingualism for students with disabilities. Importantly, studies with student participants with reading disabilities (Abu-Rabia \& Siegel, 2002; Da Fontoura \& Siegel, 1995), autism (Hambly \& Fombonne, 2012; Ohashi et al., 2012; Petersen, MarinovaTodd, \& Mirenda, 2012), language disabilities (Paradis, Crago, Genesee, \& Rice, 2003), Down syndrome (Feltmate \& KayRaining Bird, 2008; Kay-Raining Bird et al., 2005), visual impairments (Milian, 1996), and cognitive impairment (Edgin, Kumar, Spano, \& Nadel, 2011; Rueda, 1983; Whitaker, Rueda, \& Prieto, 1985) had similar outcomes: bilingual students with disabilities tended to score as well or better than comparable monolingual students with disabilities on assessed reading, communication, and cognitive skills. Moreover, when language skills are affected, students' disabilities tended to be identifiable in both of their languages. Researchers also found that associations of communication and reading skills of each of the two languages occur (i.e., learning the home language supports learning the second language).

To illustrate, Kay-Raining Bird et al. (2005) compared language outcomes (e.g., vocabulary, production and comprehension of target words in English and the home language) for bilingual children with Down syndrome to comparable (e.g., matched for developmental level) monolingual children with Down syndrome. Participants were between 2 and 11 years old, were English dominant, and spoke another language (i.e., French, Cree). The researchers found that bilingual children who had Down syndrome performed at least as well in both of their languages as their monolingual counterparts with Down syndrome, though the degree of second language proficiency for children with Down syndrome was variable. Kay-Raining Bird and colleagues concluded that "children with Down syndrome can be successful in acquiring two languages and that bilingual children perform in their dominant language (in this case English) at least as well as their monolingual counterparts with Down syndrome matched for developmental level" (p. 197).

In a study of bilingual and monolingual students' cognitive skills, Edgin et al. (2011) found that although parents of 7 to 18-year-old bilingual children with Down syndrome reported lower language comprehension abilities compared to that of matched monolingual children with disabilities, significant differences in assessed cognitive outcomes (e.g., English language and verbal intelligence) were not found between the two groups of children. Bilingual and monolingual students (both with disabilities) performed similarly on cognitive measures, meaning that bilingualism did not result in cognitive deficits. Similar results regarding assessed cognitive outcomes of bilingual children with and without disabilities were reported by Whitaker et al. (1985) and Rueda (1983).
However, in a study by Crutchley, Botting, and ContiRamsden (1997), the researchers found that monolingual children with disabilities outperformed bilingual children with disabilities. In this study, results were actually mixed. While bilingual children with language disabilities performed commensurate with monolingual children with language disabilities in several English skills (i.e., semantic and pragmatic skills), they did not perform as well as monolingual students with language disabilities on several other skills (i.e., phonology, syntax, vocabulary, appropriate behavior). Importantly, in a critique of this study, Kay-Raining Bird et al. (2005) pointed out that, despite the importance of ensuring that study participants were actually bilingual, Crutchley et al. (1997) stated bilingual participants "may or may not actually have been bilingual" (p. 268), therefore raising significant validity questions about study outcomes and conclusions.

Thus, the results of all but one of these comparison studies illustrate that bilingualism is not inherently problematic for children with disabilities. In fact, for some skills, bilingual students with disabilities outperformed monolingual students with disabilities, suggesting a bilingual advantage. Moreover, results suggested that, when students' competencies are impacted by disability, the disability is manifested in both of bilingual children's languages. Finally, cross-language association was highlighted, suggesting that learning one language positively impacted learning another.

\section{DISABILITY AND BILINGUAL INTERVENTION/INSTRUCTION}

We now turn to bilingual and monolingual intervention/ instruction for students with disabilities. Many researchers recommend bilingual instruction and intervention for students with a variety of disabilities (e.g., Baker, 2011; Cheatham et al., 2007; Kohnert, 2010; Kohnert, Yim, Nett, Kan, \& Durán, 2005; Ortiz, 1997; Paradis, Genesee, \& Crago, 2010; Thordardottir, 2010). In this section, we review studies of intervention and instruction that compared the home language and/or bilingual instruction to second-languageonly intervention/instruction for students with disabilities.

\section{Outcomes of Home Language/Bilingual Instruction Compared to Second Language Only}

Children with disabilities who participated in studies that compared home language/bilingual instruction with second language instruction only included those with speech/language disabilities (Perozzi, 1985; Perozzi \& Sanchez, 1992; Pham, Kohnert, \& Mann, 2011; Salameh, Nettelbladt, \& Norlin, 2003), cognitive disability (Duran \& Heiry, 1986; Rohena, Jitendra, \& Browder, 2002), and autism (Duran \& Heiry, 1986; Lang et al., 2011). Across these studies, researchers found that intervention/instruction that included 
the home language for bilingual children with disabilities led to equal or better communication, behavioral, and task completion outcomes than instruction provided only in the second language. Two other studies (i.e., Bruck, 1982; To, Law, \& Li, 2012) illustrated that students with language disabilities could learn another language when it was the medium of classroom instruction. See Table 1 for a matrix of study participants, variables, and outcomes. As Pham et al. (2011) noted in their study of children with language disabilities, bilingual input does not cause children's confusion. To further highlight this point, three salient studies are discussed below.

TABLE 1

Matrix of Studies of Home Language, Bilingual, and Second-Language-Only Intervention/Instruction

\begin{tabular}{|c|c|c|c|c|c|c|c|c|}
\hline Author & $N$ & $\begin{array}{l}\text { Age or } \\
\text { grade }\end{array}$ & Disability & Ethnicity & Languages & $\begin{array}{l}\text { Independent } \\
\text { variable }\end{array}$ & $\begin{array}{l}\text { Dependent } \\
\text { variable }\end{array}$ & Outcomes \\
\hline Bruck (1982) & 117 & Kinder. & SLD & $\begin{array}{l}\text { Native } \\
\text { English- } \\
\text { speaking } \\
\text { Canadians }\end{array}$ & $\begin{array}{l}\text { English (L1) } \\
\text { and French (L2) }\end{array}$ & $\begin{array}{l}\text { L1 instruction } \\
\text { compared to } \\
\text { L2 immersion }\end{array}$ & $\begin{array}{l}\text { L1 cognition, } \\
\text { academics, } \\
\text { and language; } \\
\text { L2 language }\end{array}$ & $\begin{array}{l}\text { No difference be- } \\
\text { tween } L 2 \text { immersion } \\
\text { compared to } L 1 \\
\text { only instruction }\end{array}$ \\
\hline $\begin{array}{l}\text { Duran \& } \\
\text { Heiry (1986) }\end{array}$ & 38 & $\begin{array}{l}14-25 \\
\text { years }\end{array}$ & $\begin{array}{l}\text { ID, } \\
\text { Autism }\end{array}$ & $\mathrm{HI}$ & $\begin{array}{l}\text { Spanish (L1), } \\
\text { English (L2) }\end{array}$ & $\begin{array}{l}\text { L1 cueing, } \\
\text { compared to } \\
\text { bilingual cueing } \\
\text { compared to } \\
\text { L2 cueing }\end{array}$ & $\begin{array}{l}\text { Collating and } \\
\text { filing tasks }\end{array}$ & $\begin{array}{l}\text { Overall difference } \\
\text { favoring cueing in } \\
\text { L1; difference favor- } \\
\text { ing bilingual cueing } \\
\text { compared to L2 } \\
\text { cueing }\end{array}$ \\
\hline $\begin{array}{l}\text { Lang et al. } \\
\text { (2011) }\end{array}$ & 1 & 4 years & Autism & $\mathrm{NI}$ & $\begin{array}{l}\text { Spanish (L1), } \\
\text { English (L2) }\end{array}$ & $\begin{array}{l}\text { Discrete trial } \\
\text { training (DTT) } \\
\text { in } L 1 \text { compared } \\
\text { to DTT in } L 2\end{array}$ & $\begin{array}{l}\text { Response } \\
\text { accuracy, } \\
\text { challenging } \\
\text { behaviors }\end{array}$ & $\begin{array}{l}\text { Difference favoring } \\
\text { instruction in } L 1\end{array}$ \\
\hline $\begin{array}{l}\text { Perozzi \& } \\
\text { Sanchez } \\
(1992)\end{array}$ & 38 & 1st grade & SLD & $\mathrm{NI}$ & $\begin{array}{l}\text { Spanish (L1), } \\
\text { English (L2) }\end{array}$ & $\begin{array}{l}\text { L1-/L2 instruc- } \\
\text { tion compared } \\
\text { to L2 instruction }\end{array}$ & L2 grammar & $\begin{array}{l}\text { Difference favoring } \\
\text { L1/L2 instruction }\end{array}$ \\
\hline $\begin{array}{l}\text { Pham, } \\
\text { Kohnert, \& } \\
\text { Mann (2011) }\end{array}$ & 11 & 3 years & SLD & Vietnamese & $\begin{array}{l}\text { Vietnamese (L1), } \\
\text { English (L2) }\end{array}$ & $\begin{array}{l}\text { Bilingual inter- } \\
\text { vention com- } \\
\text { pared to } \mathrm{L} 2 \\
\text { intervention; } \\
\text { attention to task }\end{array}$ & $\begin{array}{l}\mathrm{L} 1 \text { and } \mathrm{L} 2 \\
\text { vocabulary }\end{array}$ & $\begin{array}{l}\text { No difference } \\
\text { between bilingual } \\
\text { and L2 intervention }\end{array}$ \\
\hline $\begin{array}{l}\text { Rohena, } \\
\text { Jitendra \& } \\
\text { Browder (2002) }\end{array}$ & 4 & $\begin{array}{l}12-15 \\
\text { years }\end{array}$ & ID & $\mathrm{HI}$ & $\begin{array}{l}\text { Spanish (L1) } \\
\text { and English (L2) }\end{array}$ & $\begin{array}{l}\text { L1 instruction } \\
\text { compared to } \\
\text { L2 instruction }\end{array}$ & $\mathrm{L} 2$ reading & $\begin{array}{l}\text { No difference for } 3 \text { of } \\
4 \text { children; difference } \\
\text { favoring L1 instruc- } \\
\text { tion for } 1 \text { child }\end{array}$ \\
\hline $\begin{array}{l}\text { Thordardottir } \\
\text { Ellis Weismer \& } \\
\text { Smith (1997) }\end{array}$ & 1 & 4 years & SLD & Icelandic & $\begin{array}{l}\text { Icelandic (L1), } \\
\text { English (L2) }\end{array}$ & $\begin{array}{l}\text { Bilingual com- } \\
\text { pared to } L 2 \\
\text { intervention }\end{array}$ & $\begin{array}{l}\text { L2 } \\
\text { vocabulary }\end{array}$ & $\begin{array}{l}\text { No difference overall; } \\
\text { difference favoring } \\
\text { bilingual intervention } \\
\text { for a vocabulary } \\
\text { subset }\end{array}$ \\
\hline $\begin{array}{l}\text { To, Law, \& } \\
\text { Li (2012) }\end{array}$ & 37 & $5-6$ years & SLD & $\begin{array}{l}\text { Chinese } \\
\text { (Hong Kong) }\end{array}$ & $\begin{array}{l}\text { Cantonese (L1), } \\
\text { Mandarin (L2) }\end{array}$ & $\begin{array}{l}\text { L1/L2 instruc- } \\
\text { tion compared } \\
\text { to } L 1 \text { instruction }\end{array}$ & $\begin{array}{l}\text { L1 grammar, } \\
\text { vocabulary, } \\
\text { comprehen- } \\
\text { sion, word } \\
\text { definition, } \\
\text { narration }\end{array}$ & $\begin{array}{l}\text { No difference be- } \\
\text { tween L1/L2 } \\
\text { instruction and } \\
\text { L1 instruction }\end{array}$ \\
\hline
\end{tabular}

Table 1 Key

\begin{tabular}{ll}
\hline Ethnicity & Disability Labels \\
\hline$A A=$ African American & SLD = Speech/language impairment \\
$E A=$ European American & $I D=$ Intellectual disability \\
$H I=$ Hispanic & $L D=$ Learning disabilities \\
& $V I=$ Visual impairments \\
& $D S=$ Down syndrome
\end{tabular}

Miscellaneous

$\mathrm{NI}=$ No information

L1 $=$ Home language

$\mathrm{L} 2$ = Second language

DS = Down syndrome 
First, Thordardottir, Ellis Weismer, and Smith (1997) compared monolingual to bilingual intervention for Icelandic-English 4-year-old bilingual children with language impairment. During monolingual treatment, new vocabulary was presented to the child only in English; only English utterances were expanded upon by the clinician. In bilingual treatment, target vocabulary was presented to the child in both English and Icelandic; the clinician expanded upon the child's utterances in both languages. Measures of vocabulary and basic concepts as well as language sample analyses were implemented in both of the participants' languages. Researchers found no significant difference in total number of English words acquired during the bilingual and monolingual treatments. Moreover, the focal child learned more English home words (e.g., "socks," "dress," "mittens") within the bilingual treatment than the monolingual treatment. These findings led the authors to conclude that "bilingual intervention did not slow down language growth" (p. 224).

Second, Rohena et al. (2004), compared constant timedelay English-only and Spanish-only instruction of sight words for four bilingual (English-Spanish) teenagers with cognitive disabilities. The study was implemented in a selfcontained life skills classroom. Results indicated no difference in efficiency and effectiveness of English sight word acquisition between the Spanish-only and English-only instruction for three out of four of the bilingual individuals. For the fourth participant, Spanish-only instruction was most efficient and effective.

Finally, Lang et al. (2011) compared effects of using discrete trial training via English and Spanish for one 4-year-old girl diagnosed with autism to determine under which language conditions the child performed correct target behaviors. The child spoke Spanish at home and primarily used English in her education program. When instructed in Spanish, the participant produced the most correct responses and engaged in fewest challenging behaviors (i.e., distracting tongue clicks) compared to instruction using only English.

Thus, comparison studies discussed here indicate that students with disabilities tend to benefit more from instruction/intervention that includes the home language or both home and second language compared to only the second language. Including home language instruction actually facilitates rather than hinders second language (e.g., English) learning; in effect, there is cross-language association of home language and second language.

\section{DISCUSSION}

Many of the comparison studies reviewed here have important limitations and methodological weaknesses. Some studies included small numbers of participants, particularly studies investigating outcomes of home language compared to bilingual instruction. Other issues include consistency in participants' bilingual determination (i.e., extent to which the student participants were proficient in their two languages) and disability determination (i.e., degree to which culturally and linguistically appropriate disability diagnosis occurred). The difficulties with disability determination for students from diverse cultural and linguistic backgrounds are well known (e.g., Artiles, Kozleski, Trent, Osher, \& Ortiz, 2010). To take one element of appropriate evaluation procedures, some of the comparison studies reviewed here did not discuss assessment in both of the study participants' languages, as is considered best practice in evaluation (Durán, Cheatham, \& Santos, 2011).

Interpreting these comparison studies as a whole is challenging. Existing studies were primarily conducted with younger students who had language disabilities. There are a limited number of studies, particularly those investigating impacts of language of instruction for students with disabilities. Interventions were primarily conducted by the researchers in individual instructional (e.g., clinical) settings rather than in typical classroom settings. Few studies delineated contexts in which instruction occurred (i.e., ethnographic description) or referred to the cultural relevance of instructional approaches beyond using the student participants' home language. Finally, outcomes of intervention/ instruction studies most often measured the second language rather than both of the student participants' languages (Thordardottir, 2010). The extent to which these comparison studies can be generalized to a wider population of students, including those being educated within inclusive settings, is unknown.

Nonetheless, results of the comparison studies are informative and should be viewed in light of the many studies investigating student bilingualism conducted by researchers outside the field of special education. Specifically, studies comparing skills of typically developing bilingual students to those of typically developing monolingual students suggest that bilingualism does not have negative impacts on several types of skills, and, in fact, bilingualism can impart advantages compared to monolingualism, such as to working memory (e.g., Bialystok, Craik, \& Luk, 2012; Bialystok \& Shapero, 2005; Hakuta, 1987; Marinova-Todd, Zhao, \& Bernhardt, 2010), though advantages of bilingualism should not be overstated (see Bialystok, 2009, for more on this important topic). Taken together, evidence indicates that bilingualism is not problematic for children who are typically developing. Thus, the support for students' home languages as they learn English should be also considered for students with disabilities.

Equally important, outcomes of several of the comparison studies reviewed here illustrate that learning in the home 
language can facilitate learning a second language (i.e., cross-linguistic association) for bilingual students with disabilities. This provides evidence of what Cummins (1996) called the interdependency hypothesis, in that there is a common underlying language proficiency for both of a student's languages, a phenomenon also illustrated in studies with typically developing students for specific skills, such as vocabularly skills (Carlisle, Beeman, Davis, \& Spharim, 1999), phonological awareness (Durgunoglu, Nagy, \& Hancin-Bhatt, 1993), and even reading strategies (Garcia, 1998). Studies with typically developing bilingual students illustrate that, when students' home language skills are reinforced within education programs, students have a stronger cognitive and academic foundation (Cummins, 1989), though research suggests that there are limitations to interdependency (e.g., Bialystok, Majumder, \& Martin, 2003; Bialystok, McBride-Chang, \& Luk 2005).

Comparison studies reviewed here are also promising with regards to the use of the home or both home and second languages during instruction/intervention (i.e., bilingual instruction). Numerous studies with typically developing students have illustrated the effectiveness of including the home language through bilingual education programs (e.g., Durán, Roseth, \& Hoffman, 2010; Ramirez, Yuen, Ramey, \& Pasta, 1991; Thomas \& Collier, 1996; 2002; Willig, 1985). When students have an opportunity to participate in highquality education programs that include the home and second language, they can perform as well in second language skills as their peers who attend all-English programs (National Research Council, 2002). Evidence suggests that this may also be the case for bilingual students with disabilities, though more research is warranted.

\section{IMPLICATIONS}

In this section, we discuss implications of the outcomes of comparison studies investigating bilingualism and bilingual instruction/intervention for students with disabilities. Practice and research implications will be delineated.

\section{Implications for Practice}

Given the evidence that students with disabilities can be bilingual without consequence to their communication, cognition, and behavior and that some evidence exists of advantages of being bilingual, special education professionals should pursue means to use both languages with students with disabilities. Importantly, professionals can pay particular attention to those children with disabilities whose community and family are bilingual; for these children, bilingualism is particularly important (de Valenzuela \& Niccolai, 2004). For those students requiring bilingualism, bilingual special education programs can be specially designed so that bilingual students with disabilities reach their highest potential (Ehlers-Zavala, 2011), including acquisition of English, maintenance of their home language, and content learning. By providing support in both languages, educators are ensuring that students with disabilities develop each of their languages "to the best of their ability" (Kay-Raining Bird et al., 2005, p. 197).

Beyond the evidence for effectiveness of bilingual instruction, other reasons for bilingual instruction for students with disabilities are important: In addition to home language learning facilitating second language learning, Cheatham et al. (2007) asserted that bilingualism for students with disabilities (a) supports students' ability to communicate in a common language with their family, (b) provides opportunities for greater inclusion within students' communities, and (c) supports students' cultural and individual identity. Students who speak a home language other than English within the United States are at risk for home language loss (Jia \& Aaronson, 2003; Wong Fillmore, 1991). English-only instructional programs tend to be subtractive (i.e., lead to loss of home language) rather than additive (i.e., lead to competence in home language and English; Baker, 2011).

\section{At school}

Comparison studies reviewed here also suggest that bilingual special education programs may be an effective instructional approach for bilingual students with disabilities, though student learning outcomes regarding the academic content remain largely unresearched. Bilingual special education programs can be defined as "the use of the home language along with English in an individually designed program of instruction provided to a student with exceptional education needs for the purpose of maximizing his or her learning potential" (Ovando, Collier, \& Combs, 2003, p. 360 ). To fully and successfully implement bilingual instruction for students with disabilities, teamwork, planning, and an individualized approach is necessary (Hoover et al., 2008).

A critical element of this discussion is providing students with services within inclusive environments. Successful inclusion necessitates collaborative efforts of many education professionals, such as general and special educators, ESL and bilingual teachers, teacher aides, administrators, related service providers, and others, including parents (Collier, 2004), who are often excluded from decisions regarding language of instruction for their children with disabilities (Mueller, Singer, \& Carranza, 2006).

Appropriate education for bilingual students with disabilities in inclusive settings may require an array of services, such as appropriate modifications, specialized instruction, speech-language therapy, assistive technology, and teachers' aide support, potentially in both of the students' languages 
(Serpa, 2011). Teams work together to adapt instruction for students who are struggling to address needs related to both language and disability (Artiles \& Ortiz, 2002; Serpa, 2011).

Researchers have identified effective instructional strategies for bilingual students in special education programs with a particular focus on literacy learning (e.g., Enguídanos \& Ruiz, 2008; Lopez-Reyna, 1996; Ruiz, Vargas, \& Beltrán, 2002). These instructional strategies can be incorporated into models for bilingual special education. Most promising, given its research base and the fact that instruction can be provided in inclusive settings, are dual-language bilingual programs in which students use the non-English language for a significant amount of class time (e.g., 50\%) and English the remaining time (Lindholm-Leary \& Howard, 2008). The programs provide opportunities for equal numbers of native English-speaking students and students speaking a different home language to participate in integrated classes in which both languages are used one at a time during instruction. Students in these programs can learn two languages while also succeeding academically (Baker, 2011; Lindholm-Leary \& Howard, 2008). Furthermore, families and students themselves who participate in dual-language programs have indicated satisfaction with their programs (Lindholm-Leary \& Howard, 2008; Shannon \& Milian, 2002). More research is necessary to document such successes for bilingual students with disabilities.

Although dual-language programs can be effective and well liked, many states, schools, and programs may encounter obstacles to program establishment (e.g., community opposition, availability of appropriate resources). In these situations, Hoover et al. (2008) outlined models for provision of special education services to promote students' home language and English. Tapping the skills of bilingual teaching aides, ESL teachers, and monolingual educators can be considered a minimal instructional approach; an integrated bilingual special education model requires the expertise of bilingual/ESL special educators who work in collaboration with other educators. The key is to adapt these models to ensure students are appropriately included while meeting both language and disability needs. Importantly, for students to develop and maintain both languages, these approaches are less effective compared to dual-language programs.

For special education programs serving students in states that restrict instruction to English only, advocacy will be required. The federal law IDEA (2004) mandates that students receive an individualized, appropriate education but does not require English-only instruction. Because federal law pre-empts state law, states may not restrict the use of the home language for students as a part of their IEP goals if the IEP team determines that the use of the home language is appropriate. Clearly, implementation of such bilingual and home-language IEP goals can be difficult within states with English-only instructional laws (e.g., because of a lack of bilingual personnel, worry of reprisal for use of students' home languages in school, or professionals' misunderstandings of bilingual programs). However, IDEA (2004) requires IEP teams (necessarily including parents) to determine the most appropriate and beneficial instructional program for students with disabilities; given its many advantages, bilingual instruction should be considered.

Moreover, to appropriately educate bilingual students with disabilities, teacher education and training are necessary. Bilingual students with disabilities are often taught by the least prepared or qualified teachers (Artiles \& Ortiz, 2002). Special education teachers may not have training to address the needs of bilingual children with disabilities (Mueller et al., 2006). Collier (2004) suggested many competencies necessary for bilingual special educators, including knowledge of first and second language acquisition; disabilities, including language disabilities; effective instruction; means to partner with families; and many others skills. Indeed, professional development is necessary for appropriately supporting students' learning in and through both English and their home language.

\section{At Home}

Another implication of this review of comparison studies for special educators is to ensure that families make informed decisions about the use of the home and second language for their children's education programs. Professionals in multiple service fields continue to recommend that parents and other family members speak to their children only in one language (typically English). That is, families are instructed to neglect the home language because children with disabilities cannot acquire two languages and bilingualism would be detrimental to not only the children's language development but perhaps their overall development (e.g., Jegatheesan, 2011; Jordaan, 2008). Indeed, physicians, speech-language pathologists, psychologists, and teachers continue to advise parents of bilingual children with autism to use only one language even when families wish to use both the home and second language (Kay-Raining Bird et al., 2012).

At a minimum, special educators can no longer simply advise families to stop speaking their home language with a student who has a disability. Discussions with families about the importance of the home language and potential for homelanguage loss can occur with regard to student competencies and family priorities. For many families of children with disabilities, the only valid choice is the use of both languages rather than just one. Focusing only on English could result in isolating children from the multitude of linguistic contexts in which they live and learn (Kay Raining-Bird, 2009) 
and deprive families of the best means for socializing their children, who need to be full participants within their families (Wong Fillmore, 2000). Toppelberg, Snow, and TagerFlusberg (1999) suggested that the quality of home-language input for children with developmental disabilities is particularly important; consequently, they advise against using the second language at home when the parents are not highly proficient in the second language. As such, educators can provide suggestions for families to support the use of the home language with their child with a disability. Importantly, educational planning should include discussions not just of present but also future contexts that students will be expected to negotiate in one or both languages (Thordardottir, 2010). Some families may simply want that their children to use English all the time. Families' wishes, priorities, and goals for their children are important regarding educational decisions for bilingual children with disabilities and should be respected.

For those families who wish to support bilingualism for their children with disabilities, achievement of proficiency in the home language requires their deliberate efforts. As Tabors (2008) suggested, families can plan for the use and development of the home language. Reading with children in the home language, telling stories, encouraging the use of home-language media (e.g., internet, television), and participating in community events in which the home language is used will likely provide students with opportunities for home language growth (Cheatham et al., 2007). Special educators can provide important suggestions and resources for families to provide their children home language development activities.

\section{Implications for Research}

While much progress has been made regarding the provision of special education services for bilingual students with disabilities, more research is necessary. First, as has occurred during the history of special education as a discipline, the study of instructional practices for bilingual students with disabilities should be moved from controlled studies to inclusive classrooms in which multiple variables naturally occur, including accounting for feasibility of bilingual instruction for educators of students with disabilities.

A clear area for more study based on this review of comparison studies relates to students' learning of academic content. Though models for bilingual education have addressed academic outcomes for bilingual students who are typically developing (e.g., Lindholm-Leary \& Howard, 2008), no research was identified with these same outcomes for bilingual students with disabilities. To recommend with greater confidence that bilingual students with disabilities participate in bilingual education programs, more research is necessary.
Moreover, Cook (1992) and Grosjean (1998) suggest that bilinguals be viewed as legitimate language speakers rather than maintaining a bias towards monolingualism. In this way, research investigating the developmental and learning needs of bilingual students with disabilities can occur in similar ways to studies of students with specific characteristics, such as a particular disability or learning needs. Researchers can look beyond comparisons between bilingual and monolingual students with disabilities to understand their unique development and characteristics. As these are identified, instructional approaches to meet these students' needs can be developed and assessed for effectiveness.

Furthermore, future research should include not only the establishment of greater evidence for supporting home-language development for bilingual students with disabilities but should also investigate for whom and under what conditions interventions are effective for bilingual children with disabilities (Odom et al., 2005). For example, it is important to investigate when and for how long each language should be used during instruction as well as the order in which the two languages are used to obtain intended communication outcomes (Thordardottir, 2010; also see Perozzi, 1985). Furthermore, learning conditions should also include the political and sociological contexts in which bilingual students with disabilities learn, because these conditions are critical to students' success or failure. The use of appropriate research methodologies that match research questions may help better understand the processes and contexts by which children with disabilities learn two languages. To build and strengthen the knowledge base on this topic, researchers must approach the issues from multiple perspectives using appropriate methodologies to address the questions that remain unanswered today. Odom et al. (2005) recognized the need for multiple methodologies in special education research due to complexities inherent in special education service delivery. McCray and Garcia (2002) asserted that studies of disability without reference to contextual characteristics, such as culture and language, will result in incomplete results, and they therefore call for the inclusion of diverse voices and epistemologies in multicultural and bilingual special education. Qualitative research from a sociocultural and critical theory perspective has been productive in addressing this issue in particular. For instance, studies investigating bilingual students' identities and classroom social relationships (e.g., teacher-student) highlight important considerations to language acquisition and instruction that remain unaccounted for in many other research agendas (Jang \& Jiménez, 2011; Jiménez, 2000). Indeed, multiple research approaches are necessary to understand bilingual children with disabilities, their learning, and appropriate instruction. 


\section{CONCLUSION}

Appropriately meeting the educational needs of bilingual students with disabilities has become increasingly important. Though limited, comparison studies reviewed here suggest that bilingualism is possible for students with disabilities and does not have negative impacts on their language and overall development. Likewise, studies indicate that instruction incorporating the home language results in learning that is as effective or better than using only the second language for students with disabilities. In fact, these studies suggest that learning the first language has positive effects on learning a second language. Bilingual special education models may provide a means to act on these outcomes to support students' home language while also learning English and other skills. Given its potential importance to families, educators should not carelessly assert that parents stop speaking their home language to their child with a disability. Further research is necessary to more definitively delineate effective instructional models and methods for bilingual students with disabilities particularly in inclusive settings.

\section{REFERENCES}

Abu-Rabia, S., \& Siegel, L. S. (2002). Reading, syntactic, orthographic, and working memory skills of bilingual Arabic-English speaking Canadian children. Journal of Psycholinguistic Research, 31, 661-678.

Arizona Revised Statutes, $15 \S 3.1$ et seq. (2001).

Artiles, A. J., Kozleski, E. B., Trent, S. C., Osher, D., \& Ortiz, A. (2010). Justifying and explaining disproportionality, 1968-2008: A critique of underlying views of culture. Exceptional Children, 76, 279-300.

Artiles, A. J., \& Ortiz, A. A. (2002). English language learners with special education needs: Contexts and possibilities. In A. J. Artiles \& A. A. Ortiz (Eds.), English language learners with special education needs: Identification, assessment, and instruction (pp. 3-27). McHenry, IL: Center for Applied Linguistics.

Baker, C. (2011). Foundations of bilingual education and bilingualism. Tonawanda, NY: Multilingual Matters.

Bassetti, B., \& Cook, V. (2011). Relating language and cognition: The second language user. In V. Cook \& B. Bassetti (Eds.), Language and bilingual cognition (pp. 143-190). New York: Psychology Press.

Bialystok, E. (2009). Bilingualism: The good, the bad, and the indifferent. Bilingualism, language, and cognition, 12, 3-11.

Bialystok, E., Craik, F. I. M., \& Luk, G. (2012). Bilingualism: Consequences for mind and brain. Trends in Cognitive Sciences, 16, $240-250$.

Bialystok, E., Majumder, S., \& Martin, M. M. (2003). Developing phonological awareness: Is there a bilingual advantage? Applied Psycholinguistics, 24(1), 27-44.

Bialystok, E., \& Shapero, D. (2005). Ambiguous benefits: The effect of bilingualism on reversing ambiguous figures. Developmental Science, 8(6), 595-604.

Bialystok, E., McBride-Chang, C., \& Luk, G. (2005). Bilingualism, language proficiency, and learning to read in two writing systems. Journal of Educational Psychology, 97, 580-590.

Bruck, M. (1982). Language impaired children's performance in an additive bilingual education program. Applied Psycholinguistics, $3,45-60$.
California Education Code, $\$ \S 1-305$ (1998).

Carlisle, J. F., Beeman, M., Davis, L. H., \& Spharim, G. (1999). Relationship of metalinguistic capabilities and reading achievement for children who are becoming bilingual. Applied Psycholinguistics, 20, 459-478.

Cheatham, G. A., Santos, R. M., \& Ro, Y. E. (2007). Home language acquisition and retention for young children with special needs. Young Exceptional Children, 11(1), 27-39.

Collier, C. (2004). Developing instructional plans and curricula for bilingual special education students. In L. M. Baca \& H. T. Cervantes (Eds.), The bilingual special education interface (pp. 230-272). Upper Saddle River, NJ: Pearson Prentice Hall.

Cook, V. (1992). Background to the L2 user. In V. J. Cook (Ed.), Portraits of the L2 user (pp. 1-28). Tonawando, NY: Multilingual Matters.

Cobo-Lewis, A. B., Pearson, B. Z., Eilers, R. E., \& Umbel, V. C, (2002). Effects of bilingualism and bilingual education on oral and written English skills: A multifactor study of standardized test outcomes. In D. K. Oller \& E. Eilers (Eds.), Language and literacy in bilingual children (pp. 64-97). Clevedon, UK: Multilingual Matters.

Crutchley, A., Botting, N., \& Conti-Ramsden, G. (1997). Bilingualism and specific language impairment in children attending language units. European Journal of Disorders of Communication, 32, 267-276.

Cummins, J. (1989). A theoretical framework for bilingual special education. Exceptional Children, 56, 111-119.

Cummins, J. (1996). Negotiating identities: Education for empowerment in a diverse society. California Association for Bilingual Education. Ontario, Canada: Ontario Institute for Studies in Education.

Da Fontoura, H. A., \& Siegel, L. S. (1995). Reading, syntactic, and working memory skills of bilingual Portuguese-English Canadian children. Reading and Writing: An Interdisciplinary Journal, 7, 139-153.

Daunic, A. P., Correa, V. I., \& Reyes-Blanes, M. E. (2004). Teacher preparation for culturally diverse classrooms: Performance-based assessment of beginning teachers. Teacher Education in Special Education, 27, 105-118.

de Valenzuela, J. S., \& Niccolai, S. L. (2004). Language development in culturally and linguistically diverse students with special education needs. In L. M. Baca \& H .T. Cervantes (Eds.), The bilingual special education interface (pp. 124-156). Upper Saddle River, NJ: Pearson Prentice Hall.

Duran, E., \& Heiry, T. J. (1986). Comparison of Spanish only, Spanish and English only cues with handicapped students. Reading Improvement, 23(2), 138-141.

Durán, L. K., Cheatham, G. A., \& Santos, R. M. (2011). Evaluating young children who are dual language learners: Gathering and interpreting multiple sources of data to make informed decisions. In M. McLean \& P. Snyder (Eds.), Young Exceptional Children monograph series 13, Gathering information to make informed decisions: Contemporary perspectives about assessment in early intervention and early childhood special education (pp. 133-156). Missoula, MT: Council for Exceptional Children Division for Early Childhood.

Durán, L. K., Roseth, C. J., \& Hoffman, P. (2010). An experimental study comparing English-only and transitional bilingual education on Spanish-speaking preschoolers' early literacy development. Early Childhood Research Quarterly, 25, 207-217.

Durgunoglu, A. Y., Nagy, W. E., \& Hancin-Bhatt, B. (1993). Cross-language transfer of phonological awareness. Journal of Educational Psychology, 85, 453-465.

Edgin, J. O., Kumar, A., Spano, G., \& Nadel, L. (2011). Neuropsychological effects of second language exposure in Down syndrome. Journal of Intellectual Disability Research, 55, 351-356. 
Ehlers-Zavala, F. P. (2011). History of bilingual special education. In A. F. Rotatori, F. Obiakor, \& J. P. Bakken (Eds.), History of special education: Advances in Special Education (Vol. 21), 343-361.

Enguídanos, T., \& Ruiz, N. T. (2008). Shared reading for older emergent readers in bilingual classrooms. Focus on Exceptional Children, 40, 4-16.

Espinosa, L. (2010). Language and literacy for bilingual and monolingual children. In V. Washington \& J. D. Andrews (Eds.), Children of 2020: Creating a better tomorrow (pp. 73-80). Washington, DC: Community Advocates for Young Learners.

Feltmate, K., \& Kay-Raining Bird, E. (2008). Language learning in four bilingual children with Down syndrome: A detailed analysis of vocabularly and morphosyntax. Canadian Journal of SpeechLanguage Pathology and Audiology, 32, 6-20.

Fix, M., \& Passel, J. S. (2003, January). U. S. immigration: Trends and implications for schools. Presentation at National Association for Bilingual Education NCLB Implementation Institute. New Orleans, LA.

Garcia, G. E. (1998). Mexican-American bilingual students' metacognitive reading strategies: What's transferred, unique, problematic? National Reading Conference Yearbook, 47, 253-263.

Grosjean, F. (1985). The bilingual as a competent but specific speakerhearer. Journal of Multilingual and Multicultural Development, 6 , 467-477.

Grosjean, F. (1998). Studying bilinguals: Methodological and conceptual issues. Bilingualism: Language and Cognition, 1, 131-149.

Gutierrez-Clellen, V. F. (1999). Language choice in intervention with bilingual children. American Journal of Speech-Language Pathology, 8, 291-302.

Hakansson, G., Salameh, E. K., \& Nettelbladt, U. (2003). Measuring language development in bilingual children: Swedish-Arabic children with and without language impairment. Linguistics, 41(2), 255-288.

Hakuta, K. (1987). Degree of bilingualism and cognitive ability in mainland Puerto Rican children. Child Development, 58, 1372-1388.

Hambly, C., \& Fombonne, E. (2012). The impact of bilingual environments on language development in children with autism spectrum disorders. Journal of Autism and Developmental Disorders, 42, 1342-1352.

Hanson (2011). Diversity in service settings. In E. W. Lynch \& M. J. Hanson (Eds.), Developing cross-cultural competence: A guide for working with children and their families, (4th ed., pp. 2-19). Baltimore: Brookes.

Hoover, J. J., Klingner, J. K., Baca, L. M., \& Patton, J. M. (2008). Methods for teaching culturally and linguistically diverse exceptional learners. Upper Saddle River, NJ: Pearson.

Individuals with Disabilities Education Act, 20 USC $§ 1400$ (2004).

Jacobson, P. F., \& Schwartz, R. G. (2002). Morphology in incipient bilingual Spanish-speaking preschool children with specific language impairment. Applied Psycholinguistics, 23, 23-41.

Jacobson, P. F., \& Schwartz, R. G. (2005). English past tense use in bilingual children with language impairment. American Journal of Speech-Language Pathology, 14, 313-323

Jang, E., \& Jiménez, R. T. (2011). A sociocultural perspective on second language learner strategies: Focus on the impact of social context. Theory into Practice, 50, 141-148.

Jegatheesan, B. (2011). Multilingual development in children with autism: Perspectives of South Asian Muslim immigrant parents on raising a child with a communicative disorder in multilingual contexts. Bilingual Research Journal, 34, 185-200.

Jia, G., \& Aaronson, D. (2003). A longitudinal study of Chinese children and adolescents learning English in the United States. Applied Psycholinguistics, 24, 131-161.
Jiménez, R. T. (2000). Literacy and the identity development of Latina/o students. American Educational Research Journal, 37, 971-1000.

Jordaan, H. (2008). Clinical intervention for bilingual children: An international survey. Folia Phoniatrica et Logopaedica, 60, 97-105.

Kay-Raining Bird, E. (2009). Bilingualism and children with Down syndrome. Language Learning and Education, 16, 90-96.

Kay-Raining Bird, E., Cleave, P., Trudeau, N., Thordardottir, E., Sutton, A., \& Thorpe, A. (2005). The language abilities of bilingual children with Down syndrome. American Journal of Speech-Language Pathology, 14, 187-199.

Kay-Raining Bird, E., Lamond, E., \& Holden, J. (2012). Survey of bilingualism in autism spectrum disorders. International Journal of Language and Communication Disorders, 47, 52-64.

Kindler, A. L. (2002). Survey of states' limited English proficient students and available educational programs and services 2000-2001 summary report. Washington, DC: Office of English Language Acquisition, Language Enhancement and Academic Achievement for Limited English Proficient Students, Department of Education.

Kohnert, K. (2010). Bilingual children with primary language impairment: Issues, evidence and implications for clinical actions. Journal of Communication Disorders, 43, 456- 473.

Kohnert, K., Yim, D., Nett, K., Kan, P. F., \& Durán, L. (2005). Intervention with linguistically diverse preschool children: A focus on developing home languages. Language, Speech, and Hearing Services in Schools, 36, 251-263.

Lang, R., Rispoli, M., Sigafoos, J., Lancioni, G., Andrews, A., \& Ortega, L. (2011). Effects of language of instruction on response accuracy and challenging behavior in a child with autism. Journal of Behavioral Education, 20, 252-259.

Lindholm-Leary, K., \& Howard, E. R. (2008). Language development and academic achievement in two-way immersion programs. In T. W. Fortune \& D. J. Tedick (Eds.), Pathways to multilingualism: Evolving perspectives on immersion education (pp. 177-200). Tonawanda, NY: Multilingual Matters.

Lopez-Reyna, N. A. (1996). The importance of meaningful contexts in bilingual special education: Moving to whole language. Learning Disabilities Research and Practice, 11, 120-131.

Marinova-Todd, S. H., Zhao, J., \& Bernhardt, M. (2010). Phonological awareness skills in the two languages of Mandarin-English bilingual children. Clinical Linguistics \& Phonetics, 24, 387-400.

McCabe, A., \& Bliss, L. S. (2005). Narratives from Spanish-speaking children with impaired and typical language development. Imagination, Cognition, and Personality, 24(4), 331-336.

McCray, A. D., \& Garcia, S. B. (2002). The stories we must tell: Developing a research agenda for multicultural and bilingual special education. Qualitative Studies in Education, 15, 599-612.

Menken, K. (2009). No Child Left Behind and its effects on language policy. Annual Review of Applied Linguistics, 29, 103-117.

Milian, M. (1996). Knowledge of basic concepts of young students with visual impairments who are monolingual or bilingual. Journal of Visual Impairment and Blindness, 90(5), 386-399.

Mueller, T. G., Singer, G. H. S., \& Carranza, F. D. (2006). Planning and language instruction practices for students with moderate to severe disabilities who are English language learners. Research \& Practice for Persons with Severe Disabilities, 31, 242-254.

National Clearinghouse for English Language Acquisition and Language Instruction Programs. (2011a). ESL with special needs: National overview, AccELLerate, 3(3), 10-11. Retrieved from http://www.ncela.gwu.edu/files/uploads/17/Accellerate_3_3.pdf 
National Clearinghouse for English Language Acquisition and Language Instruction Programs (2011b). The growing numbers of English Learner Students 1998/99-2008/09. Retrieved from http:// www.ncela.gwu.edu/files/uploads/9/growingLEP_0809.pdf

National Research Council (2002). Minority students in special and gifted education. Washinton, DC: National Academy.

Odom, S. L., Brantlinger, E., Gersten, R., Horner, R. H., Thompson, B., \& Harris, K. (2005). Research in special education: Scientific methods and evidence-based practices. Exceptional Children, 71(2), 137-148.

Ohashi, J. K., Mirenda, P., Marinova-Todd, S., Hambly, C., Fombonne, E., ...Thompson, A. (2012). Comparing early language development in monolingual- and bilingual-exposed young children with autism spectrum disorders. Research in Autism Spectrum Disorders, 6, 890-897.

Oller, D. K., Pearson, B. Z., \& Cobo-Lewis, A. B. (2007). Profile effects in early bilingual language and literacy. Applied Psycholinguistics, 28, 191-230.

Ortiz, A. (1997). Learning disabilities occurring concomitantly with linguistic differences. Journal of Learning Disabilities, 30(3), 321-332.

Ovando, C. J., Collier, V. P., \& Combs, M. C. (2003). Bilingual and ESL classrooms: Teaching in multicultural contexts. Boston: McGrawHill.

Paradis, J., Crago, M., Genesee, F., \& Rice, M. (2003). French-English bilingual children with SLI: How do they compare with their monolingual peers? Journal of Speech, Language, and Hearing Research, 46, 113-127.

Paradis, J., Genesee, F. \& Crago, M. B. (2010). Dual language development and disorders: $A$ handbook on bilingualism and second language learning. Baltimore: Brookes.

Perozzi, J. A. (1985). A pilot study of language facilitation for bilingual handicapped children: Theoretical and intervention implications. Journal of Speech and Hearing Disorders, 50, 403-406.

Perozzi, J. A., \& Sanchez, M. L. C. (1992). The effect of instruction in $\mathrm{L} 1$ on receptive acquisition of $\mathrm{L} 2$ for bilingual children with language delay. Language, Speech, and Hearing Services in Schools, 23, 348-352.

Petersen, J. M., Marinova-Todd, S. H., \& Mirenda, P. (2012). Brief report: An exploratory study of lexical skills in bilingual children with autism spectrum disorder. Journal of Autism and Developmental Disorders, 42, 1499-1503.

Pham, G., Kohnert, K., \& Mann, D. (2011). Addressing clinician-client mismatch: A preliminary intervention study with a bilingual Vietnamese-English preschooler. Language, Speech, and Hearing Services in Schools, 42, 408-422.

Ramirez, J. D., Yuen, S. D., Ramey, D. R., \& Pasta, D. J. (1991). Longitudinal study of structured English immersion, early-exit and late-exit transitional bilingual education programs for languageminority children (final report). Washington, DC: U.S. Department of Education.

Rasmussen, M. (2009). Bilingual education programs in United States classrooms: Summary of trends. Retrieved from http://www.ncela. gwu.edu/files/rcd/BE024300/Trends_in_Bilingual_Education.pdf

Rohena, E. I., Jitendra, A. K., \& Browder, D. M. (2002). Comparison of the effects of Spanish and English constant time delay instruction on sight word reading by Hispanic learners with mental retardation. The Journal of Special Education, 36, 169-184.

Rueda, R. (1983). Metalinguistic awareness in monolingual and bilingual mildly retarded children. NABE Journal, 8, 55-68.
Ruiz, N. T., Vargas, E., \& Beltrán, A. (2002). Becoming a reader and writer in a bilingual special education classroom. Language Arts, 79, 297-309.

Salameh, E. K., Nettelbladt, U., \& Norlin, K. (2003). Assessing phonologies in bilingual Swedish-Arabic children with and without language impairment. Child Language Teaching and Therapy, 19, 338-364.

Serpa, M. B. (2011). An imperative for change: Bridging special and language learning education to ensure a free and appropriate education in the least restrictive environment for ELLs with disabilities in Massachusetts. Boston: Gastón Institute.

Shannon, S, M., \& Milian, M. (2002). Parents choose dual language programs in Colorado: A survey. Bilingual Research Journal, 26, 681-696.

Tabors, P. O. (2008). One child, two languages: Children learning English as a second language. Baltimore: Brookes.

Thomas, W. P., \& Collier, V. (1996). Language-minority student achievement and program effectiveness. National Association for Bilingual Education News, 19, 33-35.

Thomas, W. P., \& Collier, V. P. (2002). A national study of school effectiveness for language minority students' long-term academic achievement. Santa Cruz, CA: Center for Research on Education, Diversity and Excellence, University of California-Santa Cruz.

Thordardottir, E. (2010). Towards evidence-based practice in language intervention for bilingual children. Journal of Communication Disorders, 43, 523-537.

Thordardottir, E., Ellis-Weismer, S., \& Smith, M. (1997). Vocabulary learning in bilingual and monolingual clinical intervention. Child Language Teaching and Therapy, 13, 215-227.

To, C. K. S., Law, T., \& Li, X. (2012). Influence of additional language learning on first language learning in children with language disorders. International Journal of Communication Disorders, 47, 208-216.

Toppelberg, C., Snow, C., \& Tager-Flusberg, H. (1999). Severe developmental disorders and bilingualism: Clinical perspectives. Journal of the Academy of Child and Adolescent Psychiatry, 38, 1197-1199.

Turnbull, H. R., Stowe, M. J., \& Huerta, N. E. (2007). Free appropriate public education: The law and children with disabilities. Denver, CO: Love.

Verdugo, R. R., \& Flores, B. (2007). English language learners: Key issues. Education and Urban Society, 39, 167-193.

Whitaker, J. H., Rueda, R. S., \& Prieto, A. G. (1985). Cognitive performance as a function of bilingualism in students with mental retardation. Mental Retardation, 23, 302-307.

Willig, A. C. (1985). A meta-analysis of selected studies on the effectiveness of bilingual education. Review of Educational Research, $55,268-317$.

Wong Fillmore, L. (1991). When learning a second language means losing the first. Early Childhood Research Quarterly, 6, 323-347.

Wong Fillmore, L. (2000). Loss of family languages: Should educators be concerned? Theory into Practice, 39(4), 203-210.

Zehler, A. M., Fleischman, H. L., Hopstock, P. J., Stephenson, T. G., Pendzick, M. L., \& Sapru, S. (2003). Descriptive study of services to LEP students and LEP students with disabilities. Final report to the U.S. Department of Education, Office of English Language Acquisition. Arlington, VA: Development Associates, Inc. 